\title{
Penetrating the Blood-Brain Barrier with New Peptide-Porphyrin Conjugates Having anti-HIV Activity
}

\author{
Diogo A. Mendonça, Mariët Bakker, Christine Cruz-Oliveira, Vera Neves, Maria Angeles Jiménez, \\ Sira Defaus, Marco Cavaco, Ana Salomé Veiga, Iris Cadima-Couto, Miguel A. R. B. Castanho,* \\ David Andreu,* and Toni Todorovski*
}

Cite This: Bioconjugate Chem. 2021, 32, 1067-1077

Read Online

ACCESS | 네 Metrics \& More | 回 Article Recommendations | sl Supporting Information

ABSTRACT: Passing through the blood-brain barrier (BBB) to treat neurological conditions is one of the main hurdles in modern medicine. Many drugs with promising in vitro profiles become ineffective in vivo due to $\mathrm{BBB}$ restrictive permeability. In particular, this includes drugs such as antiviral porphyrins, with the ability to fight brain-resident viruses causing diseases such as HIV-associated neurocognitive disorders (HAND). In the last two decades, BBB shuttles, particularly peptide-based ones, have shown promise in carrying various payloads across the BBB. Thus, peptide-drug conjugates (PDCs) formed by covalent attachment of a BBB peptide shuttle and an antiviral drug may become key therapeutic tools in treating neurological disorders of viral origin. In this study, we have used various approaches (guanidinium, phosphonium, and

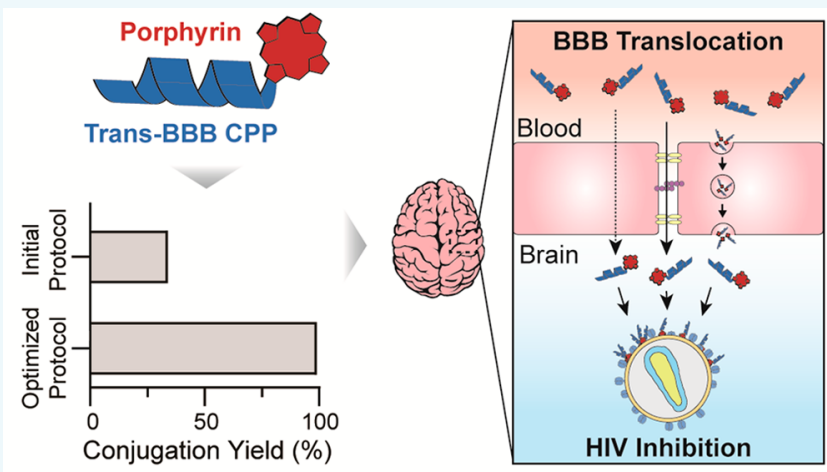
carbodiimide-based couplings) for on-resin synthesis of new peptide-porphyrin conjugates (PPCs) with BBB-crossing and potential antiviral activity. After careful fine-tuning of the synthetic chemistry, DIC/oxyma has emerged as a preferred method, by which 14 different PPCs have been made and satisfactorily characterized. The PPCs are prepared by coupling a porphyrin carboxyl group to an amino group (either $N$-terminal or a Lys side chain) of the peptide shuttle and show effective in vitro BBB translocation ability, low cytotoxicity toward mouse brain endothelial cells, and low hemolytic activity. Three of the PPCs, MP-P5, P4-MP, and P4-L-MP, effectively inhibiting HIV infectivity in vitro, stand out as most promising. Their efficacy against other brain-targeting viruses (Dengue, Zika, and SARS-CoV-2) is currently under evaluation, with preliminary results confirming that PPCs are a promising strategy to treat viral brain infections.

\section{INTRODUCTION}

Peptide-drug conjugates (PDCs) have emerged as promising therapeutic tools for treating cancer and cardiovascular, brain, and infectious diseases, and others. ${ }^{1}$ By integrating two bioactive elements into a single entity, PDCs may provide novel functionalities and bioavailabilities to treat conditions where conventional drugs are ineffective. ${ }^{1-5} \mathrm{~A}$ case in point is brain diseases where the nonpermeability of the blood-brain barrier (BBB) severely limits therapeutic options. BBB is a natural protective structure that keeps the brain safe by specifically restricting the circulation of ions, molecules, and cells between the brain and bloodstream. Its unique structure, based on specialized endothelial cells, allows tight regulation of central nervous system (CNS) homeostasis, which is critical for proper neuronal function, as well as protection from toxins, pathogens, inflammation, and so forth. In the last two decades, considerable efforts have been devoted to strategies enabling modulation and traversing of the $\mathrm{BBB}^{6-11}$ Among them, peptide-based $\mathrm{BBB}$ shuttles have proven particularly fruitful, with a number of sequences reported to effectively pass the
BBB. ${ }^{12-18}$ Recently, Neves et al. showed that some domains of the Dengue virus type 2 capsid protein (DEN2C) can become effective BBB shuttles. ${ }^{19}$ One such sequence, after penetrating the brain by adsorptive-mediated transport (AMT), is rapidly excreted back into the bloodstream, acting as a trans-BBB vector that not only ferries drug payloads into but also flushes toxins out, preventing their brain accumulation. Thus, it would seem that, by proper choice of BBB peptide shuttles, PDCs with apposite drug cargoes can virtually be developed for a broad variety of conditions affecting the CNS.

In the complex scenario caused by the current SARS-CoV-2 pandemic, as well as by other recent virus outbreaks, it is clear that effective antiviral agents will remain a main goal in drug

Received: March 11, 2021

Revised: $\quad$ May 7, 2021

Published: May 25, 2021 
development programs. A special challenge in this context is that of brain-penetrating viruses such as Zika, Dengue, SARSCoV-2, or HIV, among others, all of which pose severe health risks. $^{20-24}$ In particular, HIV-associated neurocognitive disorders (HAND) affect approximately half of the HIV-infected population. ${ }^{25}$ HAND is caused by HIV entering the CNS at the early phase of infection, ${ }^{26,27}$ persisting in that system for decades and inducing decline in thinking or cognitive functions such as memory, reasoning, judgment, problem solving, and concentration. Studies have shown that the low BBB penetration of antiretroviral drugs was associated with continued HIV replication in the CNS and higher viral loads, precluding HAND effective treatment. ${ }^{28}$

Porphyrins have been recently reported as efficient against enveloped viruses, ${ }^{29}$ a group that includes the aforementioned brain-penetrating ones. Porphyrins are tetrapyrrole macrocycles, linked by methine bonds, with the four pyrrole nitrogens defining a metal ion coordination site involved in biological processes such as respiration and photosynthesis, ${ }^{30}$ as well as in diagnostic and therapeutic applications. ${ }^{31,32}$ Their antiviral activity can be explained by two proposed mechanisms: (i) photoactivation, ${ }^{33}$ a task not simple to perform when treating brain-resident viruses; (ii) viral envelope targeting, a primary mechanism in the absence of light, where virus infectivity is blocked by porphyrin local accumulation and perturbation of the viral lipid bilayer, an approach suitable to inhibiting brain-resident viruses. Unfortunately, like other antivirals, most porphyrins are unable to cross the $\mathrm{BBB}$, which hinders their use against viral brain infections. $^{34,35}$

We hypothesized that, by conjugating a porphyrin antiviral to a trans-BBB peptide shuttle, one might circumvent the challenges to fighting viral CNS diseases, in particular, HAND. Methods for peptide-porphyrin conjugation, both in solution and in solid phase, have been described, ${ }^{36-38}$ with a growing consensus that, in terms of simplicity and expediency, on-resin conjugation offers palpable advantages over solution procedures. However, comparative studies showing how a given strategy (e.g., solution vs on-resin, coupling chemistries, etc.) is favored over others are lacking. Herein, we report the on-resin synthesis of various new peptide-porphyrin conjugates (PPCs) with BBB-crossing ability and potential antiviral activity, and compare the effectiveness of activation methods (guanidinium, phosphonium, and carbodiimide) for coupling porphyrins to resin-bound peptides. In our study, we have used six peptide shuttles (P1-P6, Table 1) and mesoporphyrin IX (MP) and protoporphyrin IX (PP) as antiviral payloads. Two shuttles, P1 and P3, have been reported as BBB-translocating, ${ }^{19}$ another (P5) has been described as the "negative image" of $\mathrm{P} 3{ }^{39}$ i.e., the result of switching cationic residues (Lys, Arg) in P3 to anionic (Glu), thereby changing the overall positive charge in P3 to negative in P5; other entries in Table 1 (P2, P4, P6) are versions of $\mathrm{P} 1, \mathrm{P} 3$, and P5, respectively, elongated with an extra Lys residue to allow $C$-terminal conjugation (Supporting Information Scheme S1). In some instances, an 8-amino-3,6-dioxaoctanoic acid $\left(\mathrm{O}_{2} \mathrm{Oc}\right)$ residue (abridged L, Table S1) is inserted between the peptide and the porphyrin units to ascertain if a spacer may modulate conjugate performance. In total, 14 novel conjugates have been obtained in high purity and satisfactorily characterized (Table S1, Figure S1). Three of them are effective in a BBB crossing cellular assay and display antiviral activity against HIV with low cytotoxicity.
Table 1. Peptide Shuttles and Porphyrins Used in This Study ${ }^{a}$

\begin{tabular}{|c|l|c|}
\hline Entry number & \multicolumn{1}{|c|}{ Structure } & $\mathrm{M}+\mathrm{H}$ \\
\hline $\mathrm{P} 1$ & VQQLTKRFSL-amide & 1218.7 \\
\hline $\mathrm{P} 2^{*}$ & VQQLTKRFS LK-amide & 1346.8 \\
\hline $\mathrm{P3}$ & AGILKRW-amide & 842.5 \\
\hline $\mathrm{P} 4^{*}$ & AGILKRWK-amide & 970.6 \\
\hline $\mathrm{P} 5$ & SGTQEEY-amide & \\
\hline $\mathrm{P} 6^{*}$ & SGTQEEYK-amide & \\
\hline &
\end{tabular}

${ }^{a} \mathrm{P} 2, \mathrm{P} 4, \mathrm{P} 6$ are versions of $\mathrm{P} 1, \mathrm{P} 3$ and $\mathrm{P} 5$, respectively, elongated with an extra Lys residue (in bold) to allow conjugation at the C-terminus.

\section{RESULTS AND DISCUSSION}

Chemistry. Conjugation between porphyrins and peptides has received considerable attention in the past decade due to the enhanced properties of the newly generated species, including the ability to overcome some of the obstacles related to porphyrin application. ${ }^{37,38,40,41}$ For example, peptide conjugation can improve poor water solubility of some porphyrins, reduce their aggregation tendency, and/or enhance porphyrin biological efficacy thanks to higher cell uptake of the conjugate vs the single porphyrin molecule. ${ }^{37,42,43}$ In parallel with the broader biological applications of PPCs, the need for optimized approaches allowing quantitative conjugation at various sites has increased. So far, several strategies using a variety of chemistries have been adopted, neither giving clear advantages over others. ${ }^{36}$ In our case, we opted for a solidphase approach, which is advantageous for its expediency. All PPCs in this work were made by an approach (Scheme 1 and Scheme S1) where a carboxyl of MP or PP is coupled to an amino group ( $N$-terminal or Lys side chain) of the CPP while it remains on the solid support, followed by acidolytic deprotection and cleavage. Thus, by combining MP and PP with six CPPs (P1 to P6) and one linker $\left(\mathrm{O}_{2} \mathrm{Oc}\right)$, a total of 14 PPCs were prepared (Table S1, Figure $\mathrm{S} 1$ ).

In devising this approach, we were aware that both MP and $\mathrm{PP}$, selected for their activity against enveloped viruses, ${ }^{29}$ each have two carboxyl groups in very similar but not strictly identical environments; i.e., the carboxyl in blue in Scheme 1 (Table 1, Scheme S1) is nine carbons away from the nearest vinyl group (ethyl in MP), while the one in green is eight carbons removed, and so forth. Coupling of those slightly unsymmetric units to a homochiral peptide will result in a mixture of two diastereomers of such structural similarity to make resolution predictably difficult. Nevertheless, we deemed this route the most expeditious one, as the more orthodox course of selectively protecting each carboxyl in MP or PP appeared too arduous and of uncertain outcome. With the above caveat in mind, we actively searched for evidence of diastereomers in the end products. LC-MS inspection by carefully chosen conditions (different ion-pairing reagents, 


\section{Scheme 1. Schematic Representation of on-Resin Synthesis of Various PPCs ${ }^{a}$}

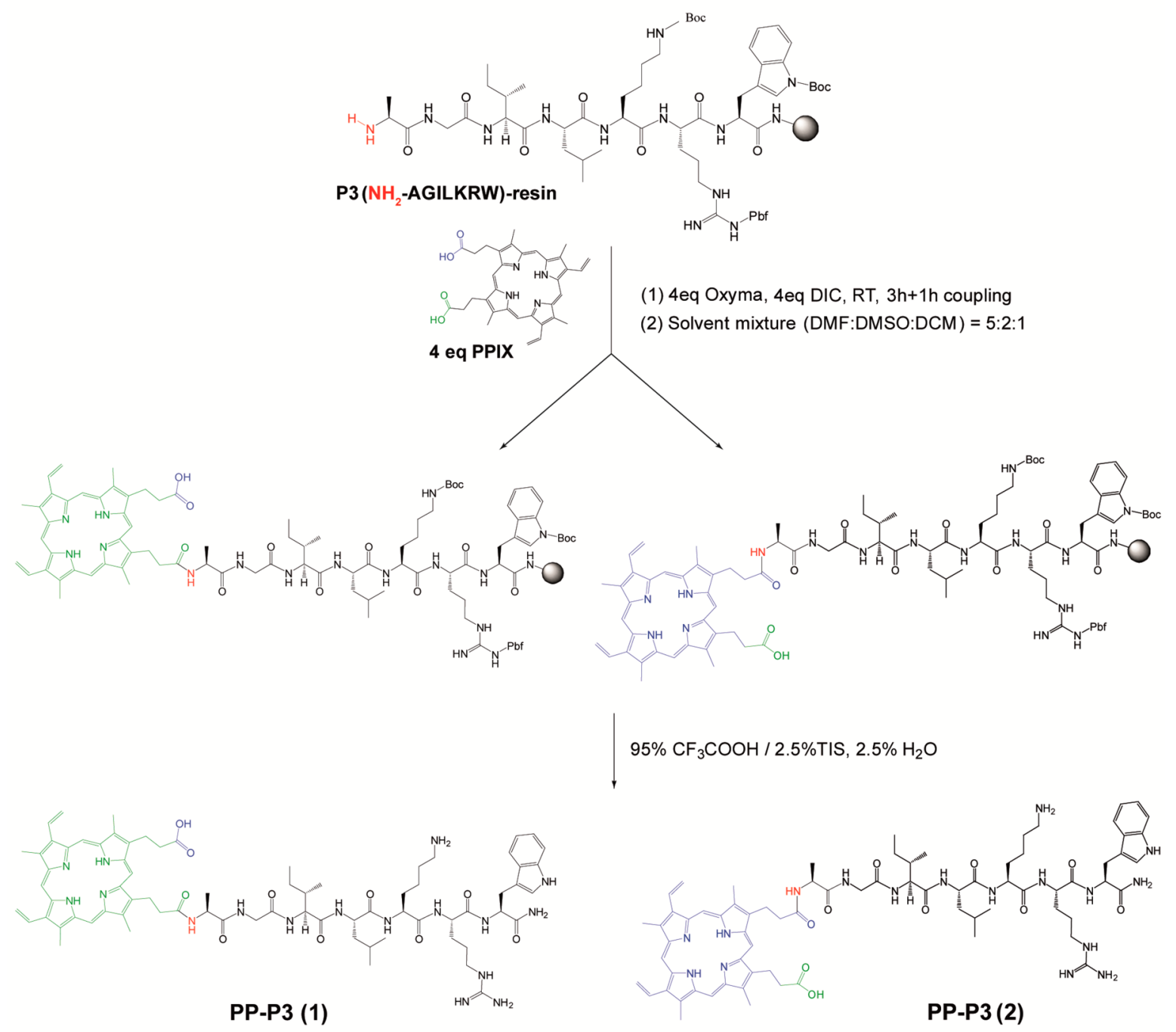

${ }^{a}$ Formation of two putative diastereomers is shown through conjugation of $-\mathrm{COOH}$ groups of $\mathrm{PP}$ with $\mathrm{N}$-terminal $\mathrm{NH}_{2}$ group of $\mathrm{P} 3$ peptide (in Scheme S1, see more details about PP conjugation with $\mathrm{P} 4$ peptide through Lys side-chain $\mathrm{NH}_{2}$ group).

shallow gradients, etc.; see Supporting Information Figures S2 and S3) affording high resolution invariably led to observing just a single peak of the expected mass. NMR analysis, on the other hand, proved more rewarding in that two different sets of signals were detectable for Ser-Phe-Leu-Lys residues in the P2MP conjugate, as clearly observed in the $2 \mathrm{D}{ }^{1} \mathrm{H},{ }^{1} \mathrm{H}$-TOCSY and $2 \mathrm{D}{ }^{1} \mathrm{H},{ }^{13} \mathrm{C}$-HSQC spectra (Figure 1). These two sets of signals can be assigned to the two putative diastereomers. That only the ${ }^{1} \mathrm{H}$ and ${ }^{13} \mathrm{C}$ chemical shifts of the residues closer to the MP moiety are affected (Figure 1, Table S2, Figures S4 and S5) is understandable by the very similar chemical environments in the two diastereomers. It was not possible to assign each set of signals to a specific diastereomer, because no distinctive NOE cross-peaks could be observed. In any case, the fact that the two sets of cross-peaks show approximately equal intensities indicates that the coupling reaction occurs with no regioselectivity.

Another concern of this work, of more practical consequence, was finding optimal conditions for high PPC yields by an on-resin approach. To this end, we explored three activation methods: (i) DIC/oxyma, (ii) guanidinium (TBTU or HATU), or (iii) phosphonium (PyBOP). Depending on the protocol, various reaction times were examined (Table 2). For DIC/oxyma, longer times (up to $3 \mathrm{~h}$ ) were preferable, while couplings mediated by more reactive guanidinium or phosphonium species were completed within $1 \mathrm{~h}$. Optimized conditions were first developed for $\mathrm{N}$-terminal conjugation, then extended to side chain conjugation (Scheme S1). The influence of solid support (ChemMatrix or Protide) and porphyrin concentration ( 0.02 vs $0.05 \mathrm{M})$ was also assessed.

LC-MS analysis (Figure 2) of end products from the three activation protocols allowed some conclusions: (i) For guanidinium or phosphonium-mediated couplings, the conversion rate-ratio of conjugate (two asterisks) to starting peptide (one asterisk) peak areas-varies substantially across porphyrin/peptide combinations (Figure 2A,B,D,E; Table 2). (ii) For DIC/oxyma, coupling time strongly influences conversion rate (Figure 2C,F; Figure 3; Table 2). (iii) Longer times do not affect the conversion rate of guanidinium or phosphonium couplings, which on the other hand tend to generate more byproducts (details in Supporting Information, Mass Spectrometry, and Table S3). Analytical data also 
A P2-MP sequence V1 Q2 Q3 L4 T5 K6 R7 F8 S9 L10 K11

B ${ }^{1} \mathrm{H},{ }^{1} \mathrm{H}$-TOCSY

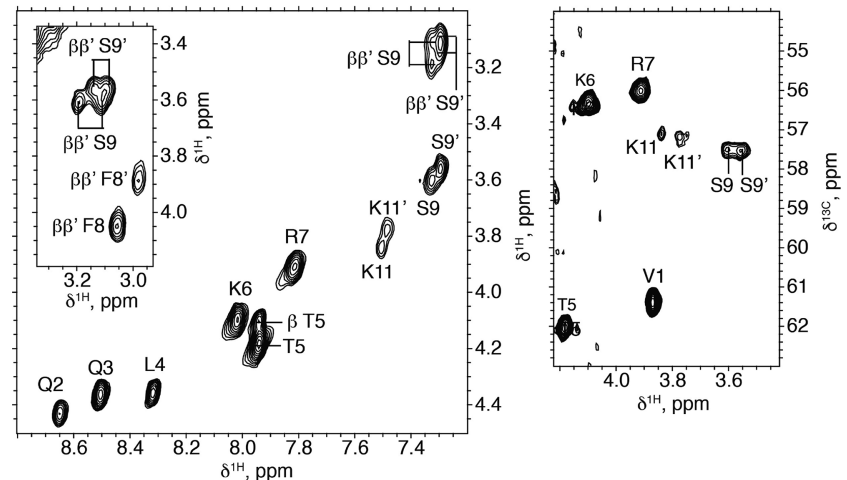

Figure 1. NMR data for conjugate P2-MP. (A) Peptide sequence where residues for which two sets of NMR signals are observed are highlighted in bold. (B) 2D ${ }^{1} \mathrm{H},{ }^{1} \mathrm{H}$-TOCSY spectral region with $\alpha$ - $\mathrm{H}^{\mathrm{N}}$ cross-peaks labeled. Some $\beta-\mathrm{H}^{\mathrm{N}}$ cross-peaks are also seen in this region. The inset shows $\alpha-\beta \beta^{\prime}$ cross-peaks for F8 and S9 in the two diastereomers. (C) $2 \mathrm{D}{ }^{1} \mathrm{H},{ }^{13} \mathrm{C}$-HSQC spectral region showing ${ }^{1} \mathrm{H} \alpha-{ }^{13} \mathrm{C} \alpha$ cross-peaks. Experimental conditions: $2 \mathrm{mM}$ peptide in $\mathrm{H}_{2} \mathrm{O} / \mathrm{D}_{2} \mathrm{O} 9: 1 \mathrm{v} / \mathrm{v}, \mathrm{pH} 3.1,45{ }^{\circ} \mathrm{C}$.

Table 2. Conjugation Conditions (Exploratory Runs) and Conversion Rates

\begin{tabular}{|c|c|c|}
\hline $\begin{array}{l}\text { porphyrin-peptide } \\
\text { combinations }\end{array}$ & $\begin{array}{l}\text { activation method/time } \\
(\mathrm{min})\end{array}$ & $\begin{array}{c}\text { conversion }^{a} \\
(\%)\end{array}$ \\
\hline \multirow[t]{4}{*}{ PP-P1 } & PyBOP-DIPEA/30 & 96.8 \\
\hline & HATU-DIPEA/60 & 100 \\
\hline & TBTU-DIPEA/30 & 97.6 \\
\hline & DIC-Oxyma/180 + 60 & 98.7 \\
\hline \multirow[t]{4}{*}{ MP-P3 } & PyBOP-DIPEA/30 & 78.9 \\
\hline & HATU-DIPEA/60 & 59.9 \\
\hline & TBTU-DIPEA/30 & 98.6 \\
\hline & $\begin{array}{l}\text { DIC-Oxyma-DIPEA/180 + } \\
\quad 60\end{array}$ & 99.5 \\
\hline \multirow[t]{2}{*}{ PP-P3 } & TBTU-DIPEA/30 & 90.1 \\
\hline & DIC-Oxyma/180 + 60 & 98.5 \\
\hline \multirow[t]{2}{*}{ MP-P1 } & TBTU-DIPEA/30 & 67.3 \\
\hline & $\begin{array}{l}\text { DIC-Oxyma-DIPEA/180 + } \\
\quad 60\end{array}$ & 97.1 \\
\hline P2-MP & $\begin{array}{l}\text { DIC-Oxyma-DIPEA/180 + } \\
60\end{array}$ & 99.6 \\
\hline P2-PP & DIC-Oxyma/180 + 60 & 99.4 \\
\hline
\end{tabular}

confirmed DIC/oxyma as the optimal activation method in terms of yield and purity. Marginal gains in conversion by guanidinium or phosphonium methods (Figure 2D,E; Table 2) tend to be offset by complex crudes whose demanding purification results in lower yields.

Having chosen DIC/oxyma as the preferred coupling method, we sought to optimize the reaction time and the number of couplings needed to achieve $>95 \%$ conversion rates. As seen in Figure 3, a $3 \mathrm{~h}$ reaction followed by a $1 \mathrm{~h}$ recoupling (termed $3 \mathrm{~h}+1 \mathrm{~h})$ led to nearly quantitative $(>98 \%)$ conversion for MP-P3 and PP-P1 (Figure 3A,B) as well as for the reverse combinations ( $>97 \%$, Figure $3 \mathrm{C})$. The optimized $3 \mathrm{~h}+1 \mathrm{~h}$ conditions afforded almost quantitative yields too in the sidechain coupling of MP or PP to P2, thus evidencing that coupling efficiency was independent of amino group position. For MP, neutralization of the hydrochloride helped avoid sluggish couplings (Figure S6). The $3 \mathrm{~h}+1 \mathrm{~h}$ conjugation was also slowed if MP or PP concentration were lowered (from 0.05 to $0.02 \mathrm{M}$ ); for near-quantitative conversions, an additional coupling $(3 \mathrm{~h}+1 \mathrm{~h}+1 \mathrm{~h})$ was required (data not shown).

We also checked the influence of the solid support on the conjugation results and could find no definite advantage between ChemMatrix Rink amide (100\% PEG-based) and Protide (PEG with a polystyrene core) resins, which were used in Prelude (conventional batch) and Liberty Blue (microwaveassisted) synthesizers, respectively (data not shown).

All the above optimization measures were finally applied to scaled-up $(50 \mu \mathrm{mol})$ PPC syntheses in which two additional CPPs, P5-a rather efficient BBB shuttle described as the "negative picture" of $\mathrm{P}^{39}$ (Table 1) - and $\mathrm{P} 6$ - for $C$-terminal conjugation-were used (Table 1). In this scaled-up format, the optimized protocols worked rather well, PPCs being obtained in $>90 \%$ purity and ca. $30 \%$ overall (synthesis + purification) yields (Table S1).

BBB in Vitro Translocation. Assessment of PPC efficacy in BBB translocation was done in a transwell setup (Figure 4A) using bEnd.3 cell monolayers. ${ }^{44}$ The bEnd.3 in vitro BBB model consists of a monolayer of cells expressing a range of essential BBB transporters, also bearing the low permeability characteristic of the BBB, suitable for this study. ${ }^{44-46}$ All conjugates achieved significant $\mathrm{BBB}$ translocation, some of them reaching levels higher than $40 \%$ (Figure $4 \mathrm{~B}$ ). With the exception of P4-MP, the conjugates did not significantly disturb monolayer integrity (Figure 4B). Unexpectedly, and in contrast with in vivo, ${ }^{34,35} \mathrm{MP}$ and $\mathrm{PP}$ translocated the monolayer. While this may be exclusive for this simple in vitro model, more studies are needed to elucidate the translocation mechanisms of porphyrins and PPCs.

HIV Inhibition. Given the potential of PPCs for BBB translocation, we next evaluated their antiviral activity. As mentioned before, porphyrins are broad-spectrum antivirals against enveloped viruses, with HIV as an example. ${ }^{29,33}$ Five conjugates, MP-P3, MP-P5, P4-MP, MP-L-P3, and P4-L-MP, were shown to inhibit HIV in vitro, with $\mathrm{IC}_{50}$ values in the $16.12-34.03 \mu \mathrm{M}$ range for $100 \mathrm{TCDI}_{50}$ and $1.38-10.69 \mathrm{mM}$ for $10 \mathrm{TCDI}_{50}$ (Table 3, Figure S7). The remaining conjugates did not inhibit HIV at non-cytotoxic concentrations (data not shown). Nonconjugated porphyrins caused no significant inhibition of HIV infectivity, in agreement with results in the absence of photoactivation. ${ }^{33}$ Overall, it is reasonable to conclude that CPP conjugation improves porphyrin efficacy by increasing membrane affinity and/or internalization, critical for the PPCs antiviral activity, ${ }^{47,48}$ in agreement with the PPCs internalization results for bEnd.3 cells (Figure S8).

Cytotoxicity. All PPCs, aside from MP-P3 at $50 \mu \mathrm{M}$, did not alter bEnd 3 cell viability, while some with $N$-terminal MP were hemolytic. Nonetheless, 9 out of 14 conjugates, including MP-P5, P4-MP, and P4-L-MP, totally lacked hemolytic activity (Table 4).

\section{CONCLUSIONS}

In conclusion, we have developed successful on-resin synthesis of new PPCs by DIC/oxyma activation strategy as most suitable and effective approach. All conjugates were well characterized, with purity $>90 \%$, displaying a single elution peak in RP-HPLC analyses. However, due to the chemical 

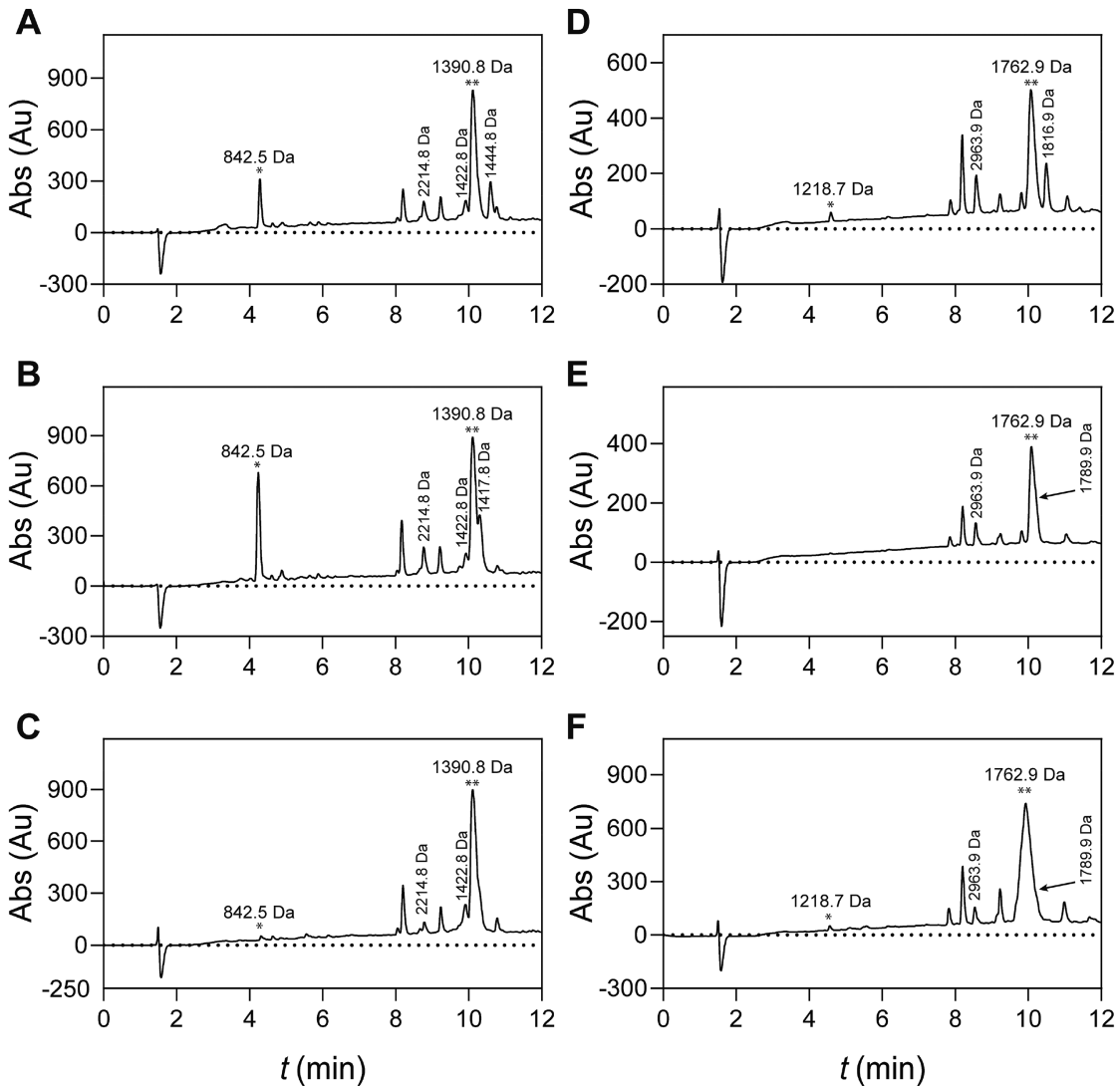

Figure 2. TIC of various conjugation strategies using MP-P3 (A-C) and PP-P1 (D-F) combinations. The ratio of peak area of conjugate (two asterisks) to that of starting peptide (one asterisk) is strongly influenced by peptide/porphyrin combinations for phosphonium (A and D) or guanidinium (B and E) mediated couplings, while for DIC/Oxyma mediated coupling, the peptide/porphyrin combination does not play a role in the final conversion rate $(\mathrm{C}$ and $\mathrm{F})$. More detailed information for the other labeled side products is given in Supporting Information.

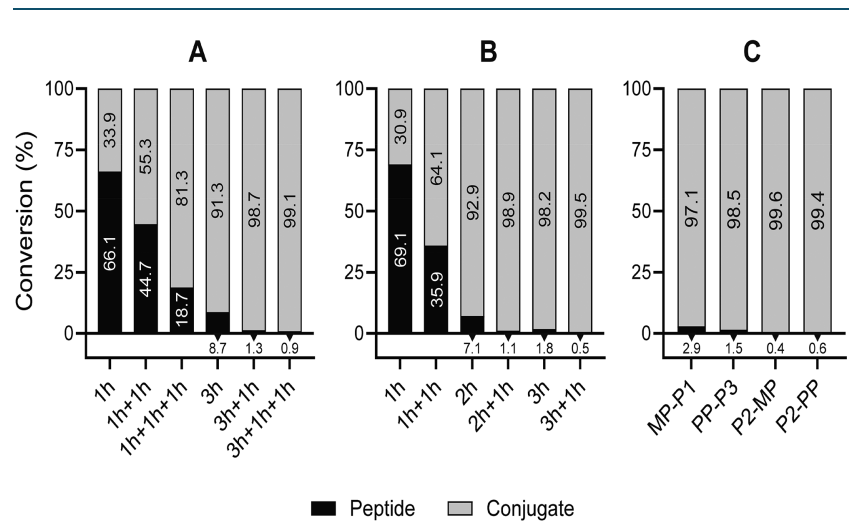

Figure 3. Optimization of DIC/Oxyma/(DIPEA)-mediated conditions for PP-P1 (A) and MP-P3 (B) conjugation. The best coupling protocol $(3 \mathrm{~h}+1 \mathrm{~h})$ was applied on both $\mathrm{N}$-terminal or side-chain conjugation combinations (C). Bars refer to peptide and conjugate integrated areas in the HPLC chromatograms of the reaction crudes.

similarity of both $-\mathrm{COOH}$ groups (in $\mathrm{MP}$ and $\mathrm{PP}$ ), the synthesized PPCs are probably a mix of two putative diastereomers - as NMR data indicates. Three of the PPCs, MP-P5, P4-MP, and P4-L-MP, were able to effectively pass the $\mathrm{BBB}$ and inhibit HIV in vitro while lacking any cytotoxic or hemolytic activity. Currently, in vitro experiments of the aforementioned PPCs (including new generation PPCs) against other brain-resident viruses (Dengue, ZIKA, and SARS-CoV-2) are ongoing.
A
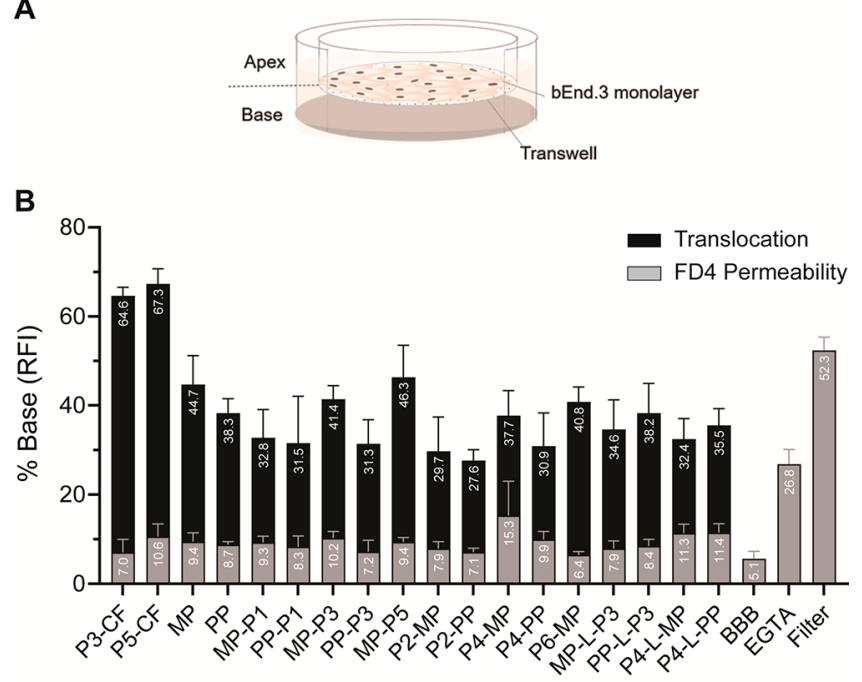

Figure 4. PPCs translocation across a bEnd.3 in vitro BBB model. (A) bEnd. 3 in vitro BBB model transwell system. The insert, or apex, corresponds to the blood side, while the base (bottom chamber) corresponds to the brain side. (B) After formation of a monolayer, 10 $\mu \mathrm{M}$ of each conjugate was added to the apical side of the tissue culture inserts. After incubation for $24 \mathrm{~h}$, samples from the basolateral side were collected, and the percentage of translocation of each conjugate (black) was calculated. FD4 permeability (gray) was measured to determine monolayer integrity post-PPCs translocation. 
Table 3. HIV inhibition by Peptide-Porphyrin Conjugates

\begin{tabular}{|c|c|c|c|c|c|}
\hline \multirow[b]{2}{*}{ Conjugates } & \multicolumn{5}{|c|}{$\mathrm{IC}_{50}(\mu \mathrm{M})$} \\
\hline & MP-P3 & MP-P5 & P4-MP & MP-L-P3 & P4-L-MP \\
\hline $100 \mathrm{TCDI}_{50}$ & $16.12 \pm 1.3$ & $33.1 \pm 1.38$ & $34.03 \pm 1.25$ & $16.59 \pm 1.29$ & $26.35 \pm 1.24$ \\
\hline $10 \mathrm{TCDI}_{50}{ }^{a}$ & $1.38 \pm 1.1$ & $10 \pm 2.9$ & $5.77 \pm 1.17$ & $1.985 \pm 1.27$ & $10.69 \pm 1.33$ \\
\hline \multicolumn{2}{|c|}{ Control } & \multicolumn{2}{|c|}{ MP } & \multicolumn{2}{|c|}{$\mathrm{PP}$} \\
\hline \multicolumn{2}{|c|}{$100 \mathrm{TCDI}_{50}$} & \multicolumn{2}{|c|}{$>50$} & \multicolumn{2}{|c|}{$>50$} \\
\hline
\end{tabular}

${ }^{a}$ Approximate physiological conditions presented in a HIV brain infection.

Table 4. Cytotoxicity of Peptide-Porphyrin Conjugates ${ }^{a}$

\begin{tabular}{|c|c|c|c|c|c|}
\hline Conjugates & MP-P1 & PP-P1 & MP-P3 & PP-P3 & MP-P5 \\
\hline $\mathrm{CC}_{50}(\mu \mathrm{M})$ & $>50$ & $>50$ & 48.19 & $>50$ & $>50$ \\
\hline $\mathrm{HC}_{50}(\mu \mathrm{M})$ & 11.33 & 19.92 & 9.1 & $>50$ & $>50$ \\
\hline Conjugates & P2-MP & P2-PP & P4-MP & P4-PP & P6-MP \\
\hline $\mathrm{CC}_{50}(\mu \mathrm{M})$ & $>50$ & $>50$ & $>50$ & $>50$ & $>50$ \\
\hline $\mathrm{HC}_{50}(\mu \mathrm{M})$ & 11.31 & $>50$ & $>50$ & $>50$ & $>50$ \\
\hline Conjugates & MP-L-P3 & PP-L-P3 & & MP & P4-L-PP \\
\hline $\mathrm{CC}_{50}(\mu \mathrm{M})$ & $>50$ & $>50$ & & & $>50$ \\
\hline $\mathrm{HC}_{50}(\mu \mathrm{M})$ & 8.88 & $>50$ & & & $>50^{a}$ \\
\hline Controls & $\mathrm{MP}$ & $\mathrm{PP}$ & $\mathrm{P} 1$ & P3 & P5 \\
\hline $\mathrm{CC}_{50}(\mu \mathrm{M})$ & $>50$ & $>50$ & $>50$ & $>50$ & $>50$ \\
\hline $\mathrm{HC}_{50}(\mu \mathrm{M})$ & $>50$ & $>50$ & $>50$ & $>50$ & $>50$ \\
\hline
\end{tabular}

${ }^{a} \mathrm{CC}_{50}: 50 \%$ cytotoxic concentration toward bEnd. 3 cells; $\mathrm{HC}_{50}: 50 \%$ lytic concentration for human erythrocytes.

\section{EXPERIMENTAL PROCEDURES}

Mesoporphyrin IX dihydrochloride and protoporphyrin IX were from Frontier Scientific, Inc. (Logan, UT, USA). HPLCgrade DMF, DCM, and acetonitrile were obtained from Fisher (Madrid, Spain), and NMP was from Sigma-Aldrich (Madrid, Spain). Fmoc-amino acids were from Iris Biotech (Marktredwitz, Germany). Water was purified in-house with a MilliQAdvantage A10 system (Merck, Madrid, Spain).

Peptide Synthesis. Peptides P1-P6 (Table 1) were built on Rink amide ChemMatrix $(0.5 \mathrm{mmoL} / \mathrm{g})$ or Protide resins $(0.54 \mathrm{mmol} / \mathrm{g})$, using Fmoc chemistry, at $0.1 \mathrm{mmoL}$ scale in either Prelude (Gyros, Tucson AZ) or Liberty Blue (CEM, Matthews, NC) instruments. Side chain protections were tertbutyl (Ser, Thr), trityl (Gln), Boc (Lys, Trp), and 2,2,4,6,7pentamethyldihydrobenzofuran-5-sulfonyl (Arg). In P2, P4, and P6 syntheses, the extra Lys at the $C$-terminal was protected with selectively removable monomethoxytrityl (Mmt). In MPL-P3, P4-L-MP, PP-L-P3, and P4-L-PP sequences (Table S1), the $\mathrm{O}_{2} \mathrm{Oc}$ spacer was coupled manually by DIC/oxyma and coupling checked by the Kaiser test. ${ }^{49}$ After completing each synthesis, a resin test cleavage (RTC) to check identity and purity was performed. Briefly, ca. $2 \mathrm{mg}$ resin was placed in an eppendorf tube and treated with $170 \mu \mathrm{L}$ of TFA-TIS- $\mathrm{H}_{2} \mathrm{O}$ $(95: 2.5: 2.5 \mathrm{v} / \mathrm{v} / \mathrm{v})$ for $90 \mathrm{~min}$ at r.t., then $1 \mathrm{~mL}$ of cold diethyl ether was added to precipitate the crude peptide. After centrifugation (12 $400 \mathrm{rpm}, 8 \mathrm{~min}$ ), supernatant was removed, and the precipitate was dried, redissolved in $15 \% \mathrm{MeCN}$ in $\mathrm{H}_{2} \mathrm{O}$, and analyzed by LC-MS (see below).

Conjugation Chemistry. For on-resin conjugations to peptides P1-P6, solvent cocktails optimized to solubilize MP and PP were, respectively, NMP:DCM:DMF 3:2:1 and DMF:DMSO:DCM 5:2:1 (v:v:v). Trial conjugations to determine optimal chemistry were performed on $5 \mu \mathrm{mol}$ peptide-resin with a $0.05 \mathrm{M}$ final concentration of either PP or $\mathrm{MP}$, in the presence of 4 equiv activator (3.9 equiv for HATU) and 8 equiv DIPEA. In DIC/oxyma-mediated MP couplings, DIPEA ( 8 equiv) neutralization of the hydrochloride salt was essential to avoid slow coupling (Figure S6). Various activation mixtures were tested in $N$-terminal conjugations: (i) PP to P1resin, PyBOP/DIPEA (30 min); HATU/DIPEA ( $1 \mathrm{~h})$; TBTU/DIPEA (30 min), or DIC/oxyma $(3+1 \mathrm{~h})$ (see Figure 2, Table 2); (ii) MP to P3-resin, PyBOP/DIPEA (30 min); HATU/DIPEA (1 h); TBTU/DIPEA (30 min) or DIC/ oxyma/DIPEA $(3+1 \mathrm{~h})$; (iii) PP to P3-resin, TBTU/DIPEA $(30 \mathrm{~min})$ or DIC/oxyma $(3+1 \mathrm{~h})$; (iv) MP to P1-resin, TBTU/DIPEA (30 min) or DIC/oxyma/DIPEA $(3+1 \mathrm{~h})$. Figure 2 shows representative HPLC traces of these trial runs from which optimal conditions were derived for the PP (DIC/ oxyma, $3 \mathrm{~h}+1 \mathrm{~h})$ and MP (DIC/oxyma/DIPEA, $3 \mathrm{~h}+1 \mathrm{~h}$ ) conjugations to the (Lys) side-chain of P2-resin, and then also generalized to other entries on Table 2. When peptide sequences with $C$-terminal Lys were used (P2, P4, P6), the side-chain $\mathrm{Mmt}$ group was selectively removed prior to porphyrin coupling by $1 \%$ TFA in DCM $(5 \times 1 \mathrm{~min})$ followed by DCM washes; the cycle was repeated until no more yellow color (presence of Mmt) was observed. The resin was then neutralized for $30 \mathrm{~s}$ with 5\% DIPEA in DCM, and porphyrin coupling was performed as above. In RTCs for these trial conjugations, cold diethyl ether (which might partially solubilize conjugates) was replaced by drying of the solution under a $\mathrm{N}_{2}$ stream. The residue was then taken up in $1.5 \mathrm{~mL}$ of $15 \% \mathrm{MeCN} / \mathrm{H}_{2} \mathrm{O}$ and analyzed by LC-MS (see below). Conversion rates were calculated from integrated peak areas of conjugate and starting peptide in the LC chromatograms.

Once an optimized conjugation protocol was chosen, largescale $(50 \mu \mathrm{mol})$ manual coupling of MP or PP to resin-bound P1-P6 was performed, followed by side chain deprotection and cleavage with $4 \mathrm{~mL}$ of $95 \%$ TFA, $2.5 \%$ TIPS, $2.5 \% \mathrm{H}_{2} \mathrm{O}$ for $3 \mathrm{~h}$. The cleavage solution was dried in a $\mathrm{N}_{2}$ stream, redissolved in $30 \% \mathrm{MeCN} / \mathrm{H}_{2} \mathrm{O}$, lyophilized, and purified by semipreparative HPLC. Overall, 14 PPCs were synthesized (Table S1) in $13-28 \%$ yield range (after HPLC purification).

Conjugate Purification. Crude lyophilized conjugates were dissolved in either $22 \% \mathrm{MeCN} / \mathrm{H}_{2} \mathrm{O}$ (P3 and P4) or $22 \% \mathrm{MeCN} / 25 \% \mathrm{DMF} / \mathrm{H}_{2} \mathrm{O}$ (P1, P2, P5, and P6) and purified by semipreparative HPLC on a LC20-AP instrument (Shimadzu, Kyoto, Japan) using Gemini $\mathrm{C}_{18}$ column $(10 \mu \mathrm{m}$, $110 \AA$, $10 \times 250 \mathrm{~mm}$, Phenomenex) and a linear 15\%-95\% $\mathrm{MeCN}$ gradient into $0.1 \%$ TFA in $\mathrm{H}_{2} \mathrm{O}$ over $40 \mathrm{~min}$ at $6 \mathrm{~mL} /$ min flow rate. Fractions were analyzed by LC-MS, and those with $>90 \%$ homogeneity were collected, lyophilized, and stored at $-20{ }^{\circ} \mathrm{C}$.

LC, LC-MS, and MALDI-MS. Purified conjugates were dissolved at $1 \mathrm{mg} / \mathrm{mL}$ in $15 \% \mathrm{MeCN}$ in $0.05 \% \mathrm{TFA} / \mathrm{H}_{2} \mathrm{O}$ for LC, LC-MS, and MALDI-MS characterization. For LC and LC-MS, $15 \mu \mathrm{L}$ were injected in an LC-20AD or LCMS-2010 EV (Shimadzu, Kyoto, Japan) instruments, correspondingly, using Aeris $\mathrm{XB}-\mathrm{C}_{18}$ column (particle size $3.6 \mu \mathrm{m}, 150 \times 4.6$ 
mm, Phenomenex, Torrance, California) and analyzed by linear $15 \%-75 \% \mathrm{MeCN}$ gradients into $0.1 \%$ TFA in $\mathrm{H}_{2} \mathrm{O}$ over $30 \mathrm{~min}$ at $1 \mathrm{~mL} / \mathrm{min}$ flow rate (for LC) or linear $10 \%-60 \%$ $\mathrm{MeCN}$ gradients into $0.1 \% \mathrm{FA}$ in $\mathrm{H}_{2} \mathrm{O}$ over $15 \mathrm{~min}$ (for LCMS) with detection over a $200-2000 \mathrm{~m} / z$ mass range (Figure S1).

MALDI-MS spectra were acquired in a 4800 Proteomics Analyzer (AB Sciex, Darmstadt, Germany) operated in positive ion mode at an acceleration voltage of $20 \mathrm{kV}, 80 \%$ grid voltage, $1.227 \mathrm{~ns}$ delay time, and $2.19 \mathrm{kV}$ detector voltage. Equal volumes of conjugate $(1 \mathrm{mg} / \mathrm{mL})$ and matrix solution $(\alpha$ cyano-4-hydroxy-cinnamic acid, $15 \mathrm{mg} / \mathrm{mL}$ in $50 \% \mathrm{MeCN}$ in $\mathrm{H}_{2} \mathrm{O}$ ) were mixed on the MALDI plate and air-dried. Spectra were recorded in reflector TOF mode in the $600-3000 \mathrm{~m} / z$ range by accumulating 30 subspectra at a fixed laser intensity of 4900.

NMR Spectroscopy. For NMR spectra acquisition, $2 \mathrm{mg}$ of lyophilized P2-MP (Tables 1 and 2) was dissolved in $0.5 \mathrm{~mL}$ of $\mathrm{H}_{2} \mathrm{O} / \mathrm{D}_{2} \mathrm{O}(9: 1 \mathrm{v} / \mathrm{v})$. The $\mathrm{pH}$ measured with a glass microelectrode was 3.2. 1D ${ }^{1} \mathrm{H}, 2 \mathrm{D}{ }^{1} \mathrm{H},{ }^{1} \mathrm{H}$-TOCSY, $2 \mathrm{D}{ }^{1} \mathrm{H},{ }^{1} \mathrm{H}$ NOESY, and $2 \mathrm{D}{ }^{1} \mathrm{H}-{ }^{13} \mathrm{C}-\mathrm{HSQC}$ were recorded at 5, 25, and $45{ }^{\circ} \mathrm{C}$ using a Bruker Avance-600 spectrometer equipped with a cryoprobe, as previously described. ${ }^{50}$ Data were processed using the TOPSPIN software (Bruker Biospin, Karlsruhe, Germany) and analyzed using the NMRFAM-SPARKY software. ${ }^{51}$

As reported for a nonpeptide MP conjugate, ${ }^{52}$ NMR signals of P2-MP were sharper at higher temperatures and were therefore assigned at $45{ }^{\circ} \mathrm{C}$ (Table S2), whereas those of the MP moiety could not be assigned because they remained broad even at $45{ }^{\circ} \mathrm{C}$.

Biological Assays of Peptide-Porphyrin Conjugates. $10 \mathrm{mM}$ conjugate solutions in DMSO were sonicated (Transsonic 460/H, Elma, Switzerland) for $10 \mathrm{~min}$; a fraction of the solution at $10 \mathrm{mM}$ was divided into $10 \mu \mathrm{L}$ aliquots, and the rest was further diluted to $2 \mathrm{mM}$ and also divided into aliquots. All aliquots were stored at $-20{ }^{\circ} \mathrm{C}$. Samples from these aliquots were used for each assay, to a final 10-50 $\mu \mathrm{M}$ concentration, with no more than $1 \%(\mathrm{v} / \mathrm{v}) \mathrm{DMSO}$ in order to keep its impact to insignificant levels. ${ }^{53}$ Conjugate samples were again sonicated twice for $3 \mathrm{~min}$ prior to use.

To avoid porphyrin photoactivation and production of reactive oxygen species, all assays described below were performed under no-light conditions: samples were handled on amber containers, with flow chamber lights and, when possible, room lights turned off. Controls under light and nolight conditions were performed to ensure reproducibility.

Cells and Cell Culture Reagents. bEnd.3 murine brain endothelioma, human embryonic kidney 293T (HEK293T), and TZM-bl cell lines were purchased from ATCC (Manassas, VA, USA). HIV-1 laboratory-adapted strain NL4-3 (HIV1NL4-3) molecular clone (pNL4-3) was provided by the NIH AIDS Research and Reference Reagent Program, Division of AIDS, NIAID, NIH (Bethesda, MD, USA). Dulbecco's Modified Eagle's Medium (DMEM), fetal bovine serum (FBS), penicillin-streptomycin (Pen-Strep), and trypsinEDTA were obtained from Gibco (Thermo-Fisher, MA, USA). The Luc-Screen luciferase detection system was obtained from Applied Biosystems (Thermo-Fisher, MA, USA). AlamarBlue reagent was purchased from Invitrogen (Thermo-Fisher).

In Vitro BBB Translocation Assay. An in vitro BBB model consisting of endothelial cells growing on the apical side of a porous membrane was used. ${ }^{46}$ bEnd. 3 cells (ATTCCCRL2299) were cultured as a monolayer on T-flasks in DMEM supplemented with $10 \%$ fetal bovine serum (FBS), $1 \%$ penicillin/streptomycin. Cells were grown in a humidified atmosphere of $5 \% \mathrm{CO}_{2}$ at $37{ }^{\circ} \mathrm{C}$ (MCO-18AIC (UV), Sanyo, Japan) with the medium changed every other day. Cells were allowed to grow until confluence in a culture T-flask, and then carefully harvested with trypsin-EDTA and seeded (3500 cells/ well) onto fibronectin-coated tissue culture 24-well inserts (transparent polyester membrane with $1.0 \mu \mathrm{m}$ pores) (BD Falcon, USA). The medium was changed every other day for 10 days, after which cells were washed twice with $1 \times$ PBS and once with DMEM medium without phenol red. Next, conjugates diluted in DMEM without phenol red to a final concentration of $10 \mu \mathrm{M}$ were added to the apical side of the in vitro BBB model (Figure 4A). Experiments were performed on different days using independently grown cell cultures.

The translocation of conjugates was determined by fluorescence intensity $\left(\lambda_{\text {exc }}=380 \mathrm{~nm}\right.$ and $\lambda_{\text {em }}=625 \mathrm{~nm}$ for $\mathrm{MP}$ conjugates, and $\lambda_{\mathrm{exc}}=380 \mathrm{~nm}$ and $\lambda_{\mathrm{em}}=675 \mathrm{~nm}$ for PP conjugates). P3-CF and P5-CF, peptides labeled with 5(6)Carboxyfluorescein (CF), were used as positive translocation controls $\left(\lambda_{\text {exc }}=492 \mathrm{~nm}\right.$ and $\left.\lambda_{\text {em }}=517 \mathrm{~nm}\right)$. After $24 \mathrm{~h}$ incubation, samples from the apical and basolateral side were collected and analyzed. Fluorescence was measured using a Varioskan Lux plate reader (Thermo Scientific, MA, USA). The percentage $(\%)$ of translocation was calculated using the following equation:

$$
\text { Translocation }(\%)=\left(\frac{F_{i}-F_{\text {cells }}}{F_{\text {conjugate }}} \times 1.25\right) \times 100
$$

where $F_{i}$ is the recovered fluorescence intensity, $F_{\text {cells }}$ is the recovered fluorescence intensity from cells without the conjugate, and $F_{\text {conjugate }}$ is the fluorescence intensity of total peptide initially added to the transwell apical side.

In Vitro BBB Integrity Assay. After $24 \mathrm{~h}$ incubation with conjugates, an in vitro integrity assay was performed. ${ }^{19}$ Briefly, cells were washed twice with PBS and once with DMEM medium without phenol red. Then, previously diluted $4 \mathrm{kDa}$ fluorescein isothiocyanate-dextran (FD4) (Sigma-Aldrich, Spain) in DMEM without phenol red to an absorbance of 0.1 was added to the apical side and incubated for $2 \mathrm{~h}$. Samples were collected from the apical and basolateral side, and fluorescence intensity was measured with $\lambda_{\text {ext }}=493 \mathrm{~nm}$ and $\lambda_{\mathrm{em}}=520 \mathrm{~nm}$, using a Varioskan Lux plate reader. The integrity of the barrier was determined as follows:

$$
\text { Permeability }(\%)=\frac{F_{i}-F_{\text {cells }}}{F_{\mathrm{FD} 4}-F_{\text {Medium }}} \times 100
$$

where $F_{\mathrm{i}}$ is the recovered fluorescence intensity, $F_{\text {cells }}$ is the recovered fluorescence intensity from cells without FD4 incubation, $F_{\mathrm{FD} 4}$ is the fluorescence intensity of total FD4 initially added to the transwell apical side, and $F_{\text {Medium }}$ is the fluorescence intensity of DMEM medium without phenol red.

Virus Culture. HEK293T and TZM-bl cell lines were cultured in DMEM supplemented with $10 \%$ (v/v) FBS and $100 \mathrm{U} / \mathrm{mL}$ Pen-Strep (complete medium), and incubated at 37 ${ }^{\circ} \mathrm{C}$, in a $5 \% \mathrm{CO}_{2}$ atmosphere. These conditions applied to all cell culture incubation periods.

Recombinant $\mathrm{HIV}-1_{\mathrm{NL} 4-3}$ viruses were produced in HEK293T cell cultures transfected with the pNL4-3 infectious 
clone through the calcium phosphate coprecipitation method. ${ }^{54,55}$ HEK293T cells were seeded at $5 \times 10^{5}$ cells/well in tissue culture-treated 6-well microplates from TPP (Trasadingen, Switzerland), and incubated for $24 \mathrm{~h}$. To prepare calciumphosphate-DNA transfection mixtures, pNL4-3 DNA (3.5 $\mu \mathrm{g} /$ well) was initially diluted in $1 \mathrm{mM}$ Tris- $\mathrm{HCl}, 0.1 \mathrm{mM}$ EDTA, $250 \mathrm{mM} \mathrm{CaCl}_{2}, \mathrm{pH} 7.6$, and then added, dropwise, to an equal volume of $50 \mathrm{mM}$ HEPES, $280 \mathrm{mM} \mathrm{NaCl}, 1.5 \mathrm{mM} \mathrm{Na}_{2} \mathrm{HPO}_{4}$, $\mathrm{pH}$ 7.05, under gentle agitation. Transfection mixtures were incubated at rt for $20 \mathrm{~min}$ before addition to cells. After $18 \mathrm{~h}$, transfection mixtures were replaced with fresh complete medium. Viral supernatants were collected $48 \mathrm{~h}$ posttransfection, centrifuged at $315 \mathrm{~g}$ for $5 \mathrm{~min}$ to remove cell debris, and stored at $-80{ }^{\circ} \mathrm{C}$ until use.

Viral supernatants harvested from pNL4-3-transfected HEK293T cells were titered through the Reed-Muench method $^{56}$ based on HIV-1 $1_{\mathrm{NL} 4-3}$ infectivity against TZM-bl cell cultures. TZM-bl cells were seeded at $2 \times 10^{4}$ cells/well in tissue culture-treated 96-well microplates from Corning (Corning, NY, USA), and incubated for $24 \mathrm{~h}$. Cells were then incubated with 2 -fold serial dilutions of viral supernatants for $3 \mathrm{~h}$, after which the supernatant was replaced with fresh complete medium. After $45 \mathrm{~h}$, TZM-bl cell infection was quantified through luciferase reporter-gene expression levels, under the control of an HIV-1 TAT-dependent LTR promoter $^{57}$ using the Luc-Screen luciferase chemiluminescence detection system. Luminescence was measured in an Infinite M200 microplate reader from Tecan (Männedorf, Switzerland). Cells were considered to be infected if the respective luminescence intensity $(L)$ was 5 -fold higher than that of control cells unexposed to virus. Titration was performed with at least four replicates to allow accurate estimation of $\mathrm{TCID}_{50}$ in viral supernatants.

In Vitro Inhibition of $\mathrm{HIV}-\mathbf{1}_{\mathrm{NL4}-3}$ Infection. The inhibitory activity of conjugates on $\mathrm{HIV}-1_{\mathrm{NL} 4-3}$ entry into TZM-bl cells was evaluated as previously described. ${ }^{58}$ TZM-bl cells were seeded at $2 \times 10^{4}$ cells/well in tissue culture-treated 96-well microplates and incubated for $24 \mathrm{~h}$. HIV-1 $1_{\mathrm{NL} 4-3}$ viral supernatants $\left(100\right.$ or $10 \mathrm{TCID}_{50} /$ well $)$ were then incubated for $1 \mathrm{~h}$ with 2 -fold serial dilutions of either nonconjugated peptide and porphyrins or conjugates, after which the infection mixture was added to TZM-bl cells. Untreated cells (in the absence of peptide-porphyrin conjugate) were used as control. Virions were incubated with cells for $3 \mathrm{~h}$, after which cells were washed to remove unbound virions and new medium was added. After $45 \mathrm{~h}$, infection was quantified by the Luc-Screen chemiluminescence assay. Measurements were performed in an Infinite M200 microplate reader. $L$ values were analyzed through nonlinear regression with the classical dose-response relationship (median-effects model based on mass action): ${ }^{59}$

$$
\begin{aligned}
& f_{\mathrm{a}}=\frac{1}{1+\left(\frac{\mathrm{IC}_{50}}{[\mathrm{EI}]}\right)^{m}} \\
& f_{\mathrm{a}}=1-\frac{L}{L_{0}}
\end{aligned}
$$

where $L_{0}$ is the luminescence intensity in the absence of the inhibitor, $\mathrm{IC}_{50}$ is the concentration that inhibits $50 \%$ of viral infection, $m$ is a slope parameter equivalent to the Hill slope, and $[\mathrm{EI}]$ is the inhibitor concentration. At least three independent experiments were performed for each assay.
Cell Viability Assay. bEnd.3 cells were plated in fibronectin precoated 96-well flat-bottom clear black polystyrene plate (Corning, New York, USA) as previously described. Cells were then cultured in complete medium at $37^{\circ} \mathrm{C}$ in a $5 \% \mathrm{CO}_{2}$ atmosphere, with medium replaced every 2 days. After 10-11 days, cells were treated with conjugate concentrations in the $6.25-50 \mu \mathrm{M}$ range for $24 \mathrm{~h}$ at $37^{\circ} \mathrm{C}$ in a $5 \% \mathrm{CO}_{2}$ atmosphere. Viability was evaluated by the CellTiterBlue assay (Promega, Wisconsin, USA), based on resazurin reduction into highly fluorescent resorufin by metabolically active cells. By distinguishing metabolic from nonmetabolic cells, cytotoxicity can be indirectly determined. After incubation, cells were washed with PBS, pH 7.4, and $15 \mu \mathrm{L}$ of CellTiterBlue reagent in $100 \mu \mathrm{L}$ of complete medium was added to the cells and incubated for $1.5 \mathrm{~h}$ at $37{ }^{\circ} \mathrm{C}$ in $5 \% \mathrm{CO}_{2}$. Fluorescence was measured at $590 \mathrm{~nm}$, with excitation at 560 $\mathrm{nm}$, using an Infinite F200 plate reader (Tecan, Switzerland). Complete medium and medium containing $0.25 \%$ Triton $\mathrm{X}$ 100 were used as positive and negative controls (100\% and $0 \%$ viability), respectively. Cell viability (\%) was determined using the following equation:

$$
\text { cell viability }(\%)=\frac{\left(F_{\text {treated }}-F_{\text {blank }}\right)}{\left(F_{\text {nontreated }}-F_{\text {blank }}\right)} \times 100
$$

where $F_{\text {treated }}$ is the fluorescence emission of conjugate-treated cells, $F_{\text {nontreated }}$ is the fluorescence emission of the control nontreated cells, and $F_{\text {blank }}$ is the fluorescent emission of CellTiter reagent in complete medium without cells.

Results are representative of at least three different independent experiments.

Hemolysis Assay. Human red blood cells (hRBCs) were obtained from human blood samples collected in EDTA tubes on the day of the experiments. $1 \mathrm{~mL}$ blood was centrifuged for $5 \mathrm{~min}$ at $4000 \mathrm{rpm}, 4{ }^{\circ} \mathrm{C}$, and the resulting pellet was washed (3X or until supernatant was clear) with TN buffer (Tris 10 $\mathrm{mM}, \mathrm{NaCl} 150 \mathrm{mM}, \mathrm{pH} 7.4$ ) by centrifugation at $4000 \mathrm{rpm}, 4$ ${ }^{\circ} \mathrm{C}$. The supernatant was discarded, and the hRBC pellets were resuspended in TN buffer ( $100 \mu \mathrm{L}$ hRBCs in $20 \mathrm{~mL}$ buffer) to give a $0.5 \%(\mathrm{v} / \mathrm{v}) \mathrm{hRBC}$ solution. hRBCs were then added to microtiter plate wells containing 2-fold dilutions of conjugate $(0.1-50 \mu \mathrm{M}$ range) in TN buffer (+1\% DMSO), with a final hRBC concentration of $0.25 \%(\mathrm{v} / \mathrm{v})$. Plates were incubated for $1 \mathrm{~h}$ at $37{ }^{\circ} \mathrm{C}$ with $100 \mathrm{rpm}$ stirring, then centrifuged for $5 \mathrm{~min}$ at $4000 \mathrm{rpm}, 4^{\circ} \mathrm{C}$, and supernatants were transferred to a 96well flat-bottom polystyrene plate (Corning). Hemolysis was assessed by hemoglobin $(\mathrm{Hb})$ release, measured by absorbance at $415 \mathrm{~nm}$ in a Varioskan LUXTM microplate reader (Thermo Fisher Scientific, Inc.). As porphyrin and $\mathrm{Hb}$ spectra are partially overlapping, to exclude porphyrin interference in $\mathrm{Hb}$ quantification a blank reading of each PPC (no hRBCs, TN buffer $+1 \%$ DMSO) was subtracted from each measurement. TN buffer (+1\% DMSO, no conjugate) and hRBCs with $1 \%$ Triton X-100 were used as negative and positive controls, respectively. Hemolysis (\%) was determined using the following equation:

$$
\operatorname{Hemolysis}(\%)=\frac{\left(\mathrm{Abs}_{\text {treated }}-\mathrm{Abs}_{\text {conjugate }}\right)}{\left(\mathrm{Abs}_{\text {Triton }}-\mathrm{Abs}_{\text {buffer }}\right)} \times 100
$$

where $\mathrm{Abs}_{\text {treated }}$ is the absorbance of $\mathrm{hRBC}$ treated with the conjugates, $\mathrm{Abs}_{\text {conjugate }}$ is the absorbance from each conjugate concentration without hRBCs, $\mathrm{Abs}_{\text {Triton }}$ is the absorbance of Triton X-100 treated hRBCs, and $\mathrm{Abs}_{\text {buffer }}$ is the absorbance of 
TN buffer alone. $\mathrm{HC}_{50}$ values were determined by GraphPad Prism 8 software using a log(inhibitor) vs normalized response (variable slope). Experiments were performed using 3 different blood donors.

\section{ASSOCIATED CONTENT}

\section{(3) Supporting Information}

The Supporting Information is available free of charge at https://pubs.acs.org/doi/10.1021/acs.bioconjchem.1c00123.

Schematic representation of conjugation through Lys side-chain $\mathrm{NH}_{2}$ group; list of all synthesized PPCs with their corresponding mass, yield, and purity; TIC-MS raw spectra of all 14 PPCs; HPLC chromatograms at various wavelengths of several PPCs; NMR characterization of P2-MP; MS characterization of some side-reaction products formed during conjugation reaction; conjugation reaction of MP with(out) DIPEA, MP-P3, MP-P5, P4-MP, MP-L-P3, and P4-L-MP cytotoxic effects against TZM-bl cells; PPC internalization into bEnd.3 cells (PDF)

\section{AUTHOR INFORMATION}

\section{Corresponding Authors}

Miguel A. R. B. Castanho - Instituto de Medicina Molecular, Faculdade de Medicina, Universidade de Lisboa, 1649-028 Lisbon, Portugal; @ orcid.org/0000-0001-7891-7562; Email: macastanho@medicina.ulisboa.pt

David Andreu - Department of Experimental and Health Sciences, Pompeu Fabra University, 08003 Barcelona, Spain; ○ orcid.org/0000-0002-6317-6666; Email: david.andreu@ upf.edu

Toni Todorovski - Department of Experimental and Health Sciences, Pompeu Fabra University, 08003 Barcelona, Spain; (1) orcid.org/0000-0002-9168-2830;

Email: toni.todorovski@upf.edu

\section{Authors}

Diogo A. Mendonça - Instituto de Medicina Molecular, Faculdade de Medicina, Universidade de Lisboa, 1649-028 Lisbon, Portugal

Mariët Bakker - Avans University of Applied Sciences, 5223 DE Breda, Netherlands

Christine Cruz-Oliveira - Instituto de Medicina Molecular, Faculdade de Medicina, Universidade de Lisboa, 1649-028 Lisbon, Portugal

Vera Neves - Instituto de Medicina Molecular, Faculdade de Medicina, Universidade de Lisboa, 1649-028 Lisbon, Portugal; (1) orcid.org/0000-0002-2989-7208

Maria Angeles Jiménez - Department of Biological Physical Chemistry, Institute of Physical Chemistry Rocasolano (IQFR-CSIC), 28006 Madrid, Spain; 이이.org/00000001-6835-5850

Sira Defaus - Department of Experimental and Health Sciences, Pompeu Fabra University, 08003 Barcelona, Spain; (1) orcid.org/0000-0002-3106-458X

Marco Cavaco - Instituto de Medicina Molecular, Faculdade de Medicina, Universidade de Lisboa, 1649-028 Lisbon, Portugal; (1) orcid.org/0000-0002-0938-9038

Ana Salomé Veiga - Instituto de Medicina Molecular, Faculdade de Medicina, Universidade de Lisboa, 1649-028 Lisbon, Portugal; 이이.org/0000-0002-9892-2243
Iris Cadima-Couto - Instituto de Medicina Molecular, Faculdade de Medicina, Universidade de Lisboa, 1649-028 Lisbon, Portugal

Complete contact information is available at:

https://pubs.acs.org/10.1021/acs.bioconjchem.1c00123

\section{Notes}

The authors declare no competing financial interest.

\section{ACKNOWLEDGMENTS}

Work supported by the La Caixa Health Foundation (project HR17_00409, ID 100010434, agreement LCF/PR/HR17/ 52150011), by the European Union (H2020-FETOPEN-20182019-2020-01 grant no 828774), and by the Spanish Ministry of Science and Innovation (AEI/FEDER grant CTQ201784371-P). NMR experiments were performed in the "Manuel Rico" NMR laboratory, LMR, CSIC, a node of the Spanish Large-Scale National Facility ICTS R-LRB. Additional funding from Fundação para a Ciência e Tecnologia (FCT-MCTES) is also acknowledged for DA Mendonça (PD/BD/136752/2018) and for C. Cruz-Oliveira and I. Cadima-Couto (PTDC/BIAVIR/29495/2017).

\section{REFERENCES}

(1) He, R., Finan, B., Mayer, J. P., and Di Marchi, R. D. (2019) Peptide conjugates with small molecules designed to enhance efficacy and safety. Molecules 24, 1855.

(2) Kwekkeboom, D. J., de Herder, W. W., Kam, B. L., van Eijck, C. H., van Essen, M., Kooij, P. P., Feelders, R. A., van Aken, M. O., and Krenning, E. P. (2008) Treatment with the radiolabeled somatostatin analog [ ${ }^{177}$ Lu-DOTA ${ }^{0}$, Tyr $^{3}$ ] octreotate: Toxicity, efficacy, and survival. J. Clin. Oncol. 26, 2124-2130.

(3) Strosberg, J., El-Haddad, G., Wolin, E., Hendifar, A., Yao, J., Chasen, B., Mittra, E., Kunz, P. L., Kulke, M. H., Jacene, H., Bushnell, D., et al. (2017) Phase 3 trial of ${ }^{177}$ Lu-Dotatate for midgut neuroendocrine tumors. N. Engl. J. Med. 376, 125-135.

(4) Letsch, M., Schally, A. V., Szepeshazi, K., Halmos, G., and Nagy, A. (2003) Preclinical evaluation of targeted cytotoxic luteinizing hormone-releasing hormone analogue AN-152 in androgen-sensitive and insensitive prostate cancers. Clin. Cancer Res. 9, 4505-4513.

(5) Li, F., and Tang, S. C. (2017) Targeting metastatic breast cancer with ANG1005, a novel peptide-paclitaxel conjugate that crosses the blood-brain-barrier (BBB). Genes \& Diseases 4, 1-3.

(6) Pardridge, W. M. (2002) Drug and gene targeting to the brain with molecular trojan horses. Nat. Rev. Drug Discovery 1, 131-139.

(7) Malakoutikhah, M., Teixidó, M., and Giralt, E. (2011) Shuttlemediated drug delivery to the brain. Angew. Chem., Int. Ed. 50, 79988014.

(8) Niewoehner, J., Bohrmann, B., Collin, L., Urich, E., Sade, H., Maier, P., Rueger, P., Stracke, J. O., Lau, W., Tissot, A. C., Loetscher, H., et al. (2014) Increased brain penetration and potency of a therapeutic antibody using a monovalent molecular shuttle. Neuron $81,49-60$.

(9) Guarnieri, D., Falanga, A., Muscetti, O., Tarallo, R., Fusco, S., Galdiero, M., Galdiero, S., and Netti, P. A. (2013) Shuttle-mediated nanoparticle delivery to the blood-brain barrier. Small 9, 853-862.

(10) Malcor, J.-D., Payrot, N., David, M., Faucon, A., Abouzid, K., Jacquot, G., Floquet, N., Debarbieux, F., Rougon, G., Martinez, J., Khrestchatisky, M., et al. (2012) Chemical optimization of new ligands of the low-density lipoprotein receptor as potential vectors for central nervous system targeting. J. Med. Chem. 55, 2227-2241.

(11) Soddu, E., Rassu, G., Giunchedi, P., Sarmento, B., and Gavini, E. (2015) From naturally-occurring neurotoxic agents to CNS shuttles for drug delivery. Eur. J. Pharm. Sci. 74, 63-76. 
(12) Oller-Salvia, B., Sánchez-Navarro, M., Giralt, E., and Teixidó, M. (2016) Blood-brain barrier shuttle peptides: An emerging paradigm for brain delivery. Chem. Soc. Rev. 45, 4690-4707.

(13) Zhang, B., Sun, X., Mei, H., Wang, Y., Liao, Z., Chen, J., Zhang, Q., Hu, Y., Pang, Z., and Jiang, X. (2013) LDLR-mediated peptide-22conjugated nanoparticles for dual-targeting therapy of brain glioma. Biomaterials 34, 9171-9182.

(14) Malakoutikhah, M., Guixer, B., Arranz-Gibert, P., Teixidó, M., and Giralt, E. (2014) 'À la carte' peptide shuttles: Tools to increase their passage across the blood-brain barrier. ChemMedChem 9, 15941601.

(15) Malakoutikhah, M., Teixidó, M., and Giralt, E. (2008) Toward an optimal blood-brain barrier shuttle by synthesis and evaluation of peptide libraries. J. Med. Chem. 51, 4881-4889.

(16) Banks, W. A. (2015) Peptides and the blood-brain barrier. Peptides 72, 16-19.

(17) Kumar, P., Wu, H., McBride, J. L., Jung, K.-E., Hee Kim, M., Davidson, B. L., Kyung Lee, S., Shankar, P., and Manjunath, N. (2007) Transvascular delivery of small interfering RNA to the central nervous system. Nature 448, 39-43.

(18) Demeule, M., Régina, A., Ché, C., Poirier, J., Nguyen, T., Gabathuler, R., Castaigne, J.-P., and Béliveau, R. (2008) Identification and design of peptides as a new drug delivery system for the brain. $J$. Pharmacol. Exp. Ther. 324, 1064-1072.

(19) Neves, V., Aires-da-Silva, F., Morais, M., Gano, L., Ribeiro, E., Pinto, A., Aguiar, S., Gaspar, D., Fernandes, C., Correia, J. D. G., and Castanho, M. A. R. B. (2017) Novel peptides derived from dengue virus capsid protein translocate reversibly the blood-brain barrier through a receptor-free mechanism. ACS Chem. Biol. 12, 1257-1268.

(20) Krauer, F., Riesen, M., Reveiz, L., Oladapo, O. T., MartínezVega, R., Porgo, T. v., Haefliger, A., Broutet, N. J., and Low, N. (2017) Zika virus Infection as a cause of congenital brain abnormalities and Guillain-Barré syndrome: Systematic review. PLOS Medicine 14, e1002203.

(21) Li, G.-H., Ning, Z.-J., Liu, Y.-M., and Li, X.-H. (2017) Neurological manifestations of dengue infection. Front. Cell. Infect. Microbiol. 7, 449.

(22) Yachou, Y., el Idrissi, A., Belapasov, V., and Ait Benali, S. (2020) Neuroinvasion, neurotropic, and neuroinflammatory events of SARS-CoV-2: Understanding the neurological manifestations in COVID-19 patients. Neurological Sciences 41, 2657-2669.

(23) González-Scarano, F., and Martín-García, J. (2005) The neuropathogenesis of AIDS. Nat. Rev. Immunol. 5, 69-81.

(24) Mustafá, Y. M., Meuren, L. M., Coelho, S. V. A., and de Arruda, L. B. (2019) Pathways exploited by flaviviruses to counteract the blood-brain barrier and invade the central nervous system. Front. Microbiol. 10, 525.

(25) Smail, R. C., and Brew, B. J. (2018) HIV-associated neurocognitive disorder. Handbook of Clinical Neurology 152, 75-97.

(26) Kramer-Hämmerle, S., Rothenaigner, I., Wolff, H., Bell, J. E., and Brack-Werner, R. (2005) Cells of the central nervous system as targets and reservoirs of the human immunodeficiency virus. Virus Res. 111, 194-213.

(27) Ghafouri, M., Amini, S., Khalili, K., and Sawaya, B. E. (2006) HIV-1 associated dementia: Symptoms and causes. Retrovirology 3, 28.

(28) Letendre, S. (2008) Validation of the CNS penetrationeffectiveness rank for quantifying antiretroviral penetration into the central nervous system. Arch. Neurol. 65, 65-70.

(29) Cruz-Oliveira, C., Almeida, A. F., Freire, J. M., Caruso, M. B., Morando, M. A., Ferreira, V. N. S., Assunção-Miranda, I., Gomes, A. M. O., Castanho, M. A. R. B., and da Poian, A. T. (2017) Mechanisms of vesicular stomatitis virus inactivation by protoporphyrin IX, Zincprotoporphyrin IX, and mesoporphyrin IX. Antimicrob. Agents Chemother. 61, e00053-17.

(30) Costa, L., Faustino, M. A. F., Neves, M. G. P. M. S., Cunha, Â., and Almeida, A. (2012) Photodynamic inactivation of mammalian viruses and bacteriophages. Viruses 4, 1034-1074.

(31) Zhang, X. -a., Lovejoy, K. S., Jasanoff, A., and Lippard, S. J. (2007) Water-soluble porphyrins as a dual-function molecular imaging platform for MRI and fluorescence zinc sensing. Proc. Natl. Acad. Sci. U. S. A. 104, 10780-10785.

(32) Hachimine, K., Shibaguchi, H., Kuroki, M., Yamada, H., Kinugasa, T., Nakae, Y., Asano, R., Sakata, I., Yamashita, Y., Shirakusa, T., and Kuroki, M. (2007) Sonodynamic therapy of cancer using a novel porphyrin derivative, DCPH-P-Na(I), which Is devoid of photosensitivity. Cancer Sci. 98, 916-920.

(33) Vzorov, A. N., Dixon, D. W., Trommel, J. S., Marzilli, L. G., and Compans, R. W. (2002) Inactivation of human immunodeficiency virus type 1 by porphyrins. Antimicrob. Agents Chemother. 46, 39173925.

(34) Terr, L., and Weiner, L. P. (1983) An autoradiographic study of $\delta$-aminolevulinic acid uptake by mouse brain. Exp. Neurol. 79, 564568.

(35) Yasuda, M., Gan, L., Chen, B., Yu, C., Zhang, J., Gama-Sosa, M. A., Pollak, D. D., Berger, S., Phillips, J. D., Edelmann, W., and Desnick, R. J. (2019) Homozygous hydroxymethylbilane synthase knock-in mice provide pathogenic insights into the severe neurological impairments present in human homozygous dominant acute intermittent porphyria. Hum. Mol. Genet. 28, 1755-1767.

(36) Giuntini, F., Alonso, C. M. A., and Boyle, R. W. (2011) Synthetic approaches for the conjugation of porphyrins and related macrocycles to peptides and proteins. Photochem. Photobiolol. Sci. 10, 759-791.

(37) Biscaglia, F., and Gobbo, M. (2018) Porphyrin-peptide conjugates in biomedical applications. Peptide Science 110, e24038.

(38) Sibrian-Vazquez, M., Jensen, T. J., Fronczek, F. R., Hammer, R. P., and Vicente, M. G. H. (2005) Synthesis and characterization of positively charged porphyrin-peptide conjugates. Bioconjugate Chem. $16,852-863$.

(39) Neves-Coelho, S., Eleutério, R., Enguita, F., Neves, V., and Castanho, M. (2017) A new noncanonical anionic peptide that translocates a cellular blood-brain barrier model. Molecules 22, 1753.

(40) Li, S. Y., Cheng, H., Qiu, W. X., Liu, L. H., Chen, S., Hu, Y., Xie, B. R., Li, B., and Zhang, X. Z. (2015) Protease-activable cellpenetrating peptide-protoporphyrin conjugate for targeted photodynamic therapy in vivo. ACS Appl. Mater. Interfaces 7, 28319-28329.

(41) Villari, V., Tosto, R., di Natale, G., Sinopoli, A., Tomasello, M. F., Lazzaro, S., Micali, N., and Pappalardo, G. (2017) A metalloporphyrin-peptide conjugate as an effective inhibitor of amyloid- $\beta$ peptide fibrillation and cytotoxicity. ChemistrySelect 2, 9122-9129.

(42) Fontenot, K. R., Ongarora, B. G., Leblanc, L. E., Zhou, Z., Jois, S. D., and Vicente, M. G. H. (2016) Targeting of the epidermal growth factor receptor with mesoporphyrin IX-peptide conjugates. J. Porphyrins Phthalocyanines 20, 352-366.

(43) Chaloin, L., Bigey, P., Loup, C., Marin, M., Galeotti, N., Piechaczyk, M., Heitz, F., and Meunier, B. (2001) Improvement of porphyrin cellular delivery and activity by conjugation to a carrier peptide. Bioconjugate Chem. 12, 691-700.

(44) Omidi, Y., Campbell, L., Barar, J., Connell, D., Akhtar, S., and Gumbleton, M. (2003) Evaluation of the immortalised mouse brain capillary endothelial cell line, b.End3, as an in vitro blood-brain barrier model for drug uptake and transport studies. Brain Res. 990, $95-112$.

(45) Yang, S., Mei, S., Jin, H., Zhu, B., Tian, Y., Huo, J., Cui, X., Guo, A., and Zhao, Z. (2017) Identification of two immortalized cell Lines, ECV304 and BEnd3, for in vitro permeability studies of blood-brain barrier. PLoS One 12, e0187017.

(46) Helms, H. C., Abbott, N. J., Burek, M., Cecchelli, R., Couraud, P.-O., Deli, M. A., Förster, C., Galla, H. J., Romero, I. A., Shusta, E. v, Stebbins, M. J., et al. (2016) In vitro models of the blood-brain barrier: An overview of commonly used brain endothelial cell culture models and guidelines for their use. J. Cereb. Blood Flow Metab. 36, 862-890.

(47) Figueira, T. N., Augusto, M. T., Rybkina, K., Stelitano, D., Noval, M. G., Harder, O. E., Veiga, A. S., Huey, D., Alabi, C. A., Biswas, S., Niewiesk, S., et al. (2018) Effective in vivo targeting of influenza virus through a cell-penetrating/fusion inhibitor tandem 
peptide anchored to the plasma membrane. Bioconjugate Chem. 29, 3362-3376.

(48) Ndeboko, B., Hantz, O., Lemamy, G., and Cova, L. (2018) Developments in cell-penetrating peptides as antiviral agents and as vehicles for delivery of peptide nucleic acid targeting hepadnaviral replication pathway. Biomolecules 8, 55 .

(49) Kaiser, E., Colescott, R. L., Bossinger, C. D., and Cook, P. I. (1970) Color test for detection of free terminal amino groups in the solid-phase synthesis of peptides. Anal. Biochem. 34, 595-598.

(50) Chaves-Arquero, B., Pérez-Cañadillas, J. M., and Jiménez, M. A. (2020) Effect of phosphorylation on the structural behaviour of peptides derived from the intrinsically disordered C-terminal domain of histone H1.0. Chem. - Eur. J. 26, 5970-5981.

(51) Lee, W., Tonelli, M., and Markley, J. L. (2015) NMRFAMSPARKY: Enhanced software for biomolecular NMR spectroscopy. Bioinformatics 31, 1325-1327.

(52) Sirish, M., Chertkov, V. A., and Schneider, H.-J. (2002) Porphyrin-based peptide receptors: Syntheses and NMR analysis. Chem. - Eur. J. 8, 1181-1188.

(53) Kurth, F., Dittrich, P. S., Walde, P., and Seebach, D. (2018) Influence of the membrane dye R18 and of DMSO on cell penetration of guanidinium-rich peptides. Chem. Biodiversity 15, e1800302.

(54) Kwon, M., and Firestein, B. L. (2013) DNA transfection: Calcium phosphate method. Methods Mol. Biol. (N. Y., NY, U. S.) 1018, 107-110.

(55) Graham, F. L., and van der Eb, A. J. (1973) A new technique for the assay of infectivity of human adenovirus 5 DNA. Virology 52, $456-467$.

(56) ReeD, L. J., and Muench, H. A. (1938) Simple method of estimating fifty per cent endpoints. Am. J. Epidemiol. 27, 493-497.

(57) Derdeyn, C. A., Decker, J. M., Sfakianos, J. N., Wu, X., O’Brien, W. A., Ratner, L., Kappes, J. C., Shaw, G. M., and Hunter, E. (2000) Sensitivity of human immunodeficiency virus type 1 to the fusion inhibitor T-20 is modulated by coreceptor specificity defined by the V3 loop of Gp120. J. Virol. 74, 8358-8367.

(58) Cunha-Santos, C., Figueira, T. N., Borrego, P., Oliveira, S. S., Rocha, C., Couto, A., Cantante, C., Santos-Costa, Q., AzevedoPereira, J. M., Fontes, C. M. G. A., Taveira, N., et al. (2016) Development of synthetic light-chain antibodies as novel and potent HIV fusion inhibitors. AIDS 30, 1691-1701.

(59) Chou, T.-C. (1976) Derivation and properties of MichaelisMenten type and Hill Type equations for reference ligands. J. Theor. Biol. 59, 253-276. 